\title{
Traditional Knowledge of Konda Dora Tribes, Visakhapatnam District, Andhra Pradesh, India
}

\author{
${ }^{1}$ S. B. Padal, ${ }^{2}$ J. Butchi Raju \& ${ }^{3}$ P. Chandrasekhar \\ 1 \& 2. Department of Botany, Mrs. A.V.N. College, Visakhapatnam-530001, Andhra Pradesh, India. \\ 3. Department of Botany, Dr. V.S. Krishna Govt. Degree College, Visakhapatnam, Andhra Pradesh, India.
}

\begin{abstract}
Visakhapatnam district of Andhra Pradesh is known for Konda Dora tribe. Konda Dora tribe is divided into a number of clans such as Korra, Killo, Swabi, Ontalu, Kimud, Pangi, Paralek, Mandelek, Bidaka, Somelunger, Surrek, Goolorigune olijukula etc., Konda Dora are very dominant in the district. Frequent field trips were conducted in Konda Dora rich areas to collect the Traditional Botanical Knowledge and Ethnomedicinal plants used by the Konda Dora. Because of modernization, all the ethno-botanical knowledge is declining day by day, so there is an urgent need to document the knowledge of ethnic people. Here 68 plant species belong to 63 genus of ethno- medicinal value were recorded from Visakhapatnam district of Andhra Pradesh, India.
\end{abstract}

Key-Words: Traditional knowledge, ethnobotany, konda dora tribe, visakhapatnam, Andhra pradesh.

\section{INTRODUCTION}

Tribal communities are considered to be forest dwellers living in harmony with their environment. They depend heavily on plants and plant products for making food, forage, fire, beverages and drinks, dye stuff and colouring matters, edible and non-edible oils, construction of dwellings, making household implements, in religious ceremonies, magico-religious rituals etc. a close association with nature has enabled tribal people to observe and scrutinize the rich flora and fauna around them for developing their own traditional knowledge and over the years, they have developed a great deal of knowledge on the use of plants and plant products as herbal remedies for various ailments.

Every country has brought out herbal and materia medica with rich folk lore, recipes, prescriptions, etc. indicating the application of crude drugs to be very ancient. Rigveda, which is considered to be the oldest available record in India, dating back to 4000-5000 B.C. recounts some medicinal plants. Atharvaveda, another religious book of Hindus, has described about 2000 plants having medicinal properties. Sushruta Samhita (1000 B.C.) further records the medicinal virtues of 700 plants. Later on, there have been a number of workers from time to time who have described the medicinal importance of plants, namely Chrak, Watts, Kirtikar and Basu, Chopra, Nadkarni, etc. our present day knowledge of Indian Materia Medica accounts for nearly 3500 species under various crude drugs, both of indigenous and exotic origin.

Medicinal plants are nature's gift to mankind and are rich heritage of India. 22India is well known as an "Emporium of medicinal plants". About $70 \%$ of the rural folk depend on medicinal plants for their health care. The Third World nations of Asia are rich in biodiversity and the indigenous knowledge particularly the traditional ethnomedical practices. India is a treasure of biodiversity which host a large variety of plants and ranks tenth among plant rich countries of the world and fourth among the Asian countries.

India is considered as one of the 12 mega-biodiversity countries of the world having rich vegetation of about 45,000 vascular plants, with concentrated hotspots in the regions of Eastern Himalayas, Western Ghats and Andaman \& Nicobar Islands. Of these, the folk medicine system of India use about 5,000 plant species with about 25,000 formulations for treating a variety of ailments, whereas the tribal medicine involves the use of over 8,000 wild plants with about $1,75,000$ specific preparations/applications. The classical indigenous systems of Indian medicine prescribe 10,000 designated formulations.

There are Ethnobotanical works either based on an ethnic tribe or on phytotherapy of a disease. Anonymous (1966) provided the information on Koyas of Andhra Pradesh. Hemadri (1981) reported the tribal medicine for rheumatism and Hemadri \& Rao (1983, 1984) enlisted the plant species for leucorrhoea, menorrhagia and jaundice. Ramarao et al. (1984) presented the note on Ethnobotanical studies in Andhra Pradesh while Ramarao (1988) did his Ph.D. work on the Ethnobotany of Eastern Ghats in Andhra Pradesh. 


\section{STUDY AREA}

Visakhapatnam district with an area of $11,161 \mathrm{Km}^{2}(4.1 \%$ of the area of the state) is one of the north

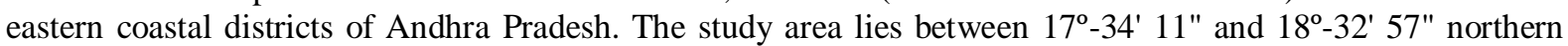
latitude and $18^{\circ}-51^{\prime} 49^{\prime \prime}$ and $83^{\circ}-16^{\prime} 9^{\prime \prime}$ in eastern longitude. It is bounded on the north partly by Orissa state and partly by Vizianagaram district, on south by East Godavari district, on west by Orissa state and east by Bay of Bengal with 43 mandals, of which 11 (Chinthapalli, Koyyuru, G.K.Veedhi, G.Madugula, Paderu, Pedabayalu, Munching put, Hukumpeta, Dumbriguda, Araku valley and Ananthagiri) are situated in the hilly areas known as the agency area (Fig. 1). The entire agency track covers 6, $298 \mathrm{Km}^{2}$ i. e., $56.4 \%$ of the total geographical area of the district. There are several peaks between 1300 to $1670 \mathrm{~m}$. Sambarikonda near Gudem village is ca $1670 \mathrm{~m}$, Kappalakonda is ca $1589 \mathrm{~m}$ and Dharakonda is $1365 \mathrm{~m}$ in altitude.

Several rivers like Machkund, Sarada, Varaha, Tandava and Goshtani flows through the district. The Machkund river rises in Madugula hill of Visakhapatnam district and flows north at first as a border between Orissa and Andhra Pradesh for some distance. In the downstream it is known as 'Sileru'. This river joins Godavari river at 'Motu'. Sarada river origin in Madugula hills and flows through Chodavaram, Anakapalli and Yelamanchili mandalas of the district. 'Varaha' river raises in the Narsipatnam hills. Both Sarada and Varaha rivers merge in Bay of Bengal near Vanthada village. Thandava origins in Chinthapalli mandal, runs through Narsipatnam and Yelamanchili mandals and joins the Bay of Bengal at Pentakota village. Gosthani has its origin near Borra caves and merges in Bay of Bengal near Konada. In addition to these, there are several hill streams that water the district.

The Konda Doras are found chiefly in the scheduled areas of Visakhapatnam District of Andhra Pradesh.. They call themselves as Kubing or Kondargi in their own dialect, which is called Kubi. Konda Doras living in Visakhapatnam can speak adivasi Oriya and Telugu. Konda Dora tribe is divided into a number of clans such as Korra, Killo, Swabi, Ontalu, Kmud, Pangi, Paralek, Mandelek, Bidaka, Somelunger, Surrek, Goolorigune olijukula etc., Levirate type of marriage is customarily practiced in this community. Polygyny is also in vogue. Marriage by capture, marriage by elopement, marriage by negotiations and marriage by service are traditionally accepted ways of acquiring mates. Divorce is socially permitted. They eat beef and pork. They are basically shifting cultivators. But they are adopting to settle cultivation. They collect and sell Non-timber forest produce (Minor Forest Produce). They worship 'Boda Devatha', 'Sanku Devata, 'Nisani Devata' Jakara Devata' and offer sacrifices. They celebrate 'Chitra Panduga', 'Balli Panduga', Korra and Sama Kotha, 'Chikudu Kotha; and pusapandoi (ceremonial eating of adda nuts). The most important festivals are 'Kada Pandoi' (seed charming festival) and this festival is followed by hunting festival. The men and women folk jointly perform the traditional colourful dance viz., Bison horn on festive and marriage occasion. One of the men folk wears headgear made up of bison horn and one or two among them carries big drums and Konda Reddy men and women dance together rhythmically to the tune of the drums.

\section{METHODOLOGY}

Ethnobotanical survey was conducted by repeated interviews and conversations with aged ethnic people, local herbal healers, shepherds, tribal headmen, owners of cattle herds, etc. in different seasons for the years. Several field trips were conducted between the years 2012 to 2013 in the district to record the ethno botanical knowledge of the Konda dora. The data were collected through questionnaires, discussions among the tribal people. The information on useful plant species, parts used, local names and mode of utilization was collected. The data collected were further verified and cross-checked in different tribal Gudems (Hamlets). Plants used in their daily needs were also collected. Plants used in their traditional medicinal uses were identified with the help of regional floras (Gamble \& Fischer, 1935). The plant voucher specimens were pressed and deposited in the Herbarium of Botany Department, Andhra University, Visakhapatnam, and Andhra Pradesh, India. The sorted information on ethno botanical knowledge of tribal inhabitants is tabulated alphabetically by botanical names of plants, name of the family, vernacular names in Telugu, habit, parts used and uses that includes medicinal or any other purpose (Table 1).

TABLE. 1. Ethnomedicinal plants used by the Konda Dora tribes of Visakhapatnam.

\begin{tabular}{|l|l|l|l|l|}
\hline Botanical name & Family & $\begin{array}{l}\text { Vernacul } \\
\text { ar name }\end{array}$ & Habit & Mode of administration \& Dosage \\
\hline Abrus precatorius Linn. & Fabaceae & Guriginja & Straggler & $\begin{array}{l}\text { COUGH \& CATARRH: Two spoons of leaf juice is taken daily } \\
\text { once or two spoons of leaf decoction is administered daily twice. }\end{array}$ \\
\hline $\begin{array}{l}\text { Acacia rugata } \text { (Lam.) } \\
\text { Ham. }\end{array}$ & $\begin{array}{l}\text { Mimosace } \\
\text { ae }\end{array}$ & Sikaya & Straggler & $\begin{array}{l}\text { LEUCODERMA: Pod powder mixed with cow urine is made into } \\
\text { paste and applied on the affected areas. }\end{array}$ \\
\hline $\begin{array}{l}\text { Acanthospermum } \\
\text { hispidum DC. }\end{array}$ & $\begin{array}{l}\text { Asteracea } \\
\text { e }\end{array}$ & $\begin{array}{l}\text { Pothoro } \\
\text { konta }\end{array}$ & Herb & $\begin{array}{l}\text { CUTS \& WOUNDS: Leaves are crushed with those of Tridax } \\
\text { procumbens } \text { and tied to affected areas. }\end{array}$ \\
\hline Acorus calamus Linn. & Araceae & Vasa & Herb & FEVER: Rhizome paste is applied all over the body and a pinch of \\
\hline
\end{tabular}




\begin{tabular}{|c|c|c|c|c|}
\hline & & & & $\begin{array}{l}\text { rhizome or leaf paste is administered with a glass of water only once } \\
\text { to keep away evil spirits causing fever. }\end{array}$ \\
\hline $\begin{array}{l}\text { Aegle marmelos (Linn.) } \\
\text { Correa }\end{array}$ & Rutaceae & Maredu & Tree & $\begin{array}{l}\text { JAUNDICE \& PILES: Half cup of leaf decoction mixed with a } \\
\text { pinch of dried ginger powder, long pepper and pepper of equal } \\
\text { quantities are administered orally once a day. }\end{array}$ \\
\hline Agave cantula Roxb. & $\begin{array}{l}\text { Agavacea } \\
\text { e }\end{array}$ & Kithanara & Herb & $\begin{array}{l}\text { LEUCODERMA: Crushed leaf juice is applied on affected areas. Do } \\
\text { not take non-vegetarian food during the course of treatment }\end{array}$ \\
\hline $\begin{array}{l}\text { Ageratum conyzoides } \\
\text { Linn. }\end{array}$ & $\begin{array}{l}\text { Asteracea } \\
\mathrm{e}\end{array}$ & Pumpullu & Herb & $\begin{array}{l}\text { ITCHINGS: Equal quantities of leaves and turmeric are ground into } \\
\text { paste and mixed with triple the amount of coconut oil, boiled and } \\
\text { applied on the affected areas. }\end{array}$ \\
\hline Ailanthus excelsa Roxb. & $\begin{array}{l}\text { Simaroub } \\
\text { aceae }\end{array}$ & $\begin{array}{l}\text { Pedda } \\
\text { manu }\end{array}$ & Tree & $\begin{array}{l}\text { LEUCORRHOEA\& MENORRHAGIA: Stem bark is crushed and } \\
\text { soaked in the fresh liquor for } 2 \text { days. One glass of filtrate is } \\
\text { administered once a day for three days. }\end{array}$ \\
\hline $\begin{array}{l}\text { Alangium salvifolium } \\
\text { (Linn.f.) Wang. }\end{array}$ & $\begin{array}{l}\text { Alangiace } \\
\text { ae }\end{array}$ & $\begin{array}{l}\text { Ooduga } \\
\text { chettu }\end{array}$ & Tree & $\begin{array}{l}\text { DIABETES: Flower buds mixed with Phyllanthus emblica fruit and } \\
\text { turmeric in equal quantities are made into powder. One spoon of it } \\
\text { mixed with honey is administered once a day. }\end{array}$ \\
\hline Basella rubra Linn. & $\begin{array}{l}\text { Basellacea } \\
\text { e }\end{array}$ & $\begin{array}{l}\text { Bacchali } \\
\text { koora }\end{array}$ & Herb & $\begin{array}{l}\text { DYSPEPSIA: Leaves are made into pickle by adding garlic and red } \\
\text { chillies and eaten quite often. }\end{array}$ \\
\hline $\begin{array}{l}\text { Bauhinia vahlii Wight \& } \\
\text { Arn. }\end{array}$ & $\begin{array}{l}\text { Caesalpini } \\
\text { aceae }\end{array}$ & Addaku & Liana & $\begin{array}{l}\text { BLOOD DYSENTERY: One small cup of stem bark decoction is } \\
\text { administered daily thrice for } 4-5 \text { days. }\end{array}$ \\
\hline $\begin{array}{l}\text { Benincasa hispida } \\
\text { (Thunb.) Cogn. }\end{array}$ & $\begin{array}{l}\text { Cucurbita } \\
\text { ceae }\end{array}$ & $\begin{array}{l}\text { Budithagu } \\
\text { mmadi }\end{array}$ & Creeper & $\begin{array}{l}\text { STOMACHACHE \& ULCER PAINS: Dried fruit pieces are fried, } \\
\text { powdered and mixed with } 2 \mathrm{~g} \text { of dried ginger and administered orally } \\
\text { with water. }\end{array}$ \\
\hline $\begin{array}{l}\text { Brassica nigra (Linn.) } \\
\text { Koch. }\end{array}$ & $\begin{array}{l}\text { Brassicace } \\
\text { ae }\end{array}$ & Varnavalu & Herb & $\begin{array}{l}\text { RHEUMATOID ARTHRITIS: Seed oil with tiger fat oil }(5: 1) \text { is } \\
\text { massaged over the affected areas daily twice for one week. }\end{array}$ \\
\hline $\begin{array}{l}\text { Butea monosperma } \\
\text { (Lam.) Taub. }\end{array}$ & Fabaceae & Moduga & Tree & $\begin{array}{l}\text { CONTRACEPTIVE: Seed paste mixed with honey and ghee is } \\
\text { applied on the vagina during menses to avoid pregnancy. }\end{array}$ \\
\hline Butea superba Roxb. & Fabaceae & Palasamu & Tree & $\begin{array}{l}\text { SNAKE BITE: Flowers are ground with the leaves of Cinnamomum } \\
\text { zeylanicum and the paste is administered orally twice a day. }\end{array}$ \\
\hline Caladium bicolor Vent. & Araceae & $\begin{array}{l}\text { Rudra } \\
\text { chama }\end{array}$ & Herb & $\begin{array}{l}\text { SNAKE BITE: Quarter cup of tuber juice is given and a portion of it } \\
\text { is applied on the bitten area immediately after bite. }\end{array}$ \\
\hline $\begin{array}{l}\text { Calycopteris floribunda } \\
\text { Lam. }\end{array}$ & $\begin{array}{l}\text { Verbenace } \\
\text { ae }\end{array}$ & $\begin{array}{l}\text { Adavijam } \\
\text { a }\end{array}$ & Shrub & $\begin{array}{l}\text { WOUNDS \& BOILS: Stem bark paste is applied on the affected } \\
\text { areas twice a day till cure. }\end{array}$ \\
\hline Cannabis sativa Linn. & $\begin{array}{l}\text { Cannabina } \\
\text { ceae }\end{array}$ & Ganjai & Herb & $\begin{array}{l}\text { DIARRHOEA: Handful of leaves are ground into paste and given } \\
\text { orally with water, daily once till cure. }\end{array}$ \\
\hline $\begin{array}{l}\text { Cardiospermum } \\
\text { halicacabum Linn. }\end{array}$ & $\begin{array}{l}\text { Sapindace } \\
\text { ae }\end{array}$ & $\begin{array}{l}\text { Budda } \\
\text { kakara }\end{array}$ & Climber & $\begin{array}{l}\text { ITCHINGS: Leaves are ground along with } 6 \text { big pepper grains and } 3 \\
\text { small pepper grains and applied on the affected areas. }\end{array}$ \\
\hline $\begin{array}{l}\text { Cascabela thevetia (Linn.) } \\
\text { Lipp. }\end{array}$ & $\begin{array}{l}\text { Apocynac } \\
\text { eae }\end{array}$ & $\begin{array}{l}\text { Paccha } \\
\text { ganneru }\end{array}$ & Tree & $\begin{array}{l}\text { RINGWORM \& SCABIES: Handful of leaves are pounded with } 2 \\
\text { spoons of fresh turmeric and the paste is applied on the affected areas } \\
\text { for half an hour twice a day till cure. }\end{array}$ \\
\hline Cassia alata Linn. & $\begin{array}{l}\text { Caesalpini } \\
\text { aceae }\end{array}$ & $\begin{array}{l}\text { Seema } \\
\text { avisa }\end{array}$ & Shrub & $\begin{array}{l}\text { BRONCHITIS: Half cup of leaf decoction mixed with a pinch of } \\
\text { pepper powder is administered daily in the morning. }\end{array}$ \\
\hline Cassia fistula Linn. & $\begin{array}{l}\text { Caesalpini } \\
\text { aceae }\end{array}$ & Rela & Tree & $\begin{array}{l}\text { SKIN DISEASES: Stem bark and leaf juice mixed with coconut oil is } \\
\text { applied on the affected areas for ringworm, rashes and leprosy. }\end{array}$ \\
\hline $\begin{array}{l}\text { Celosia argentea Linn. } \\
\text { var. plumose }\end{array}$ & $\begin{array}{l}\text { Amaranth } \\
\text { aceae }\end{array}$ & $\begin{array}{l}\text { Errakodij } \\
\text { uttu }\end{array}$ & Herb & $\begin{array}{l}\text { ULCERS IN STOMACH: Leaves and flowers in equal quantities are } \\
\text { made into juice and half glass of it is administered daily once. }\end{array}$ \\
\hline $\begin{array}{l}\text { Chlorophytum } \\
\text { arundinaceum Baker }\end{array}$ & Liliaceae & Bhudenda & Herb & $\begin{array}{l}\text { GALACTAGOGUE: Two spoons of tuberous root paste mixed in a } \\
\text { glass of goat milk is administered daily twice for } 3 \text { days. }\end{array}$ \\
\hline $\begin{array}{l}\text { Cipadessa baccifera } \\
\text { (Roth) Miq. }\end{array}$ & Meliaceae & $\begin{array}{l}\text { Randabill } \\
\text { a }\end{array}$ & Shrub & $\begin{array}{l}\text { CHIKENPOX: Leaves are ground with turmeric. Paste is applied on } \\
\text { the affected areas. }\end{array}$ \\
\hline $\begin{array}{l}\text { Cissampelos pareira } \\
\text { Linn. }\end{array}$ & $\begin{array}{l}\text { Menisper } \\
\text { maceae }\end{array}$ & $\begin{array}{c}\text { Chiru } \\
\text { boddhi }\end{array}$ & Climber & $\begin{array}{l}\text { DIARRHOEA \& PILES: One spoon of root powder mixed with } \\
\text { curd is administered daily. }\end{array}$ \\
\hline $\begin{array}{l}\text { Cissus quadrangularis } \\
\text { Linn. }\end{array}$ & Vitaceae & Nalleru & Climber & $\begin{array}{l}\text { BONE FRACTURE: Stem ground with stem bark of Polyalthia } \\
\text { longifolia is plastered on the broken parts and the plaster is changed } \\
\text { once in three days. }\end{array}$ \\
\hline Cleome gynandra Linn. & $\begin{array}{l}\text { Cleomace } \\
\text { ae }\end{array}$ & $\begin{array}{l}\text { Ventumk } \\
\text { ura }\end{array}$ & Herb & $\begin{array}{l}\text { PARALYSIS: Three to five drops of leaf juice is instilled into the ear } \\
\text { opposite to the paralytic part. Thus if right area is affected it is poured } \\
\text { into left ear and vice-versa. }\end{array}$ \\
\hline $\begin{array}{l}\text { Clerodendrum serratum } \\
\text { (Linn.) Moon. }\end{array}$ & $\begin{array}{l}\text { Verbenace } \\
\text { ae }\end{array}$ & $\begin{array}{l}\text { Seetha } \\
\text { chettu }\end{array}$ & Shrub & $\begin{array}{l}\text { HEADACHE: Leaf juice mixed with equal quantities of gingelly oil } \\
\text { and butter is heated and applied on the forehead. }\end{array}$ \\
\hline $\begin{array}{l}\text { Diplocyclos palmatus } \\
\text { (Linn.) Jeffrey }\end{array}$ & $\begin{array}{l}\text { Cucurbita } \\
\text { ceae }\end{array}$ & $\begin{array}{l}\text { Linga } \\
\text { donda }\end{array}$ & Climber & $\begin{array}{l}\text { FERTILITY: Quarter spoon of seed powder is administered with } \\
\text { milk to break sterility. }\end{array}$ \\
\hline Dillenia indica Linn. & $\begin{array}{l}\text { Dilleniace } \\
\text { ae }\end{array}$ & $\begin{array}{l}\text { Revadach } \\
\text { ettu }\end{array}$ & Tree & $\begin{array}{l}\text { STOMACHACHE: One spoon of stem bark paste is administered } \\
\text { with water. }\end{array}$ \\
\hline
\end{tabular}




\begin{tabular}{|c|c|c|c|c|}
\hline $\begin{array}{l}\text { Eclipta prostrata (Linn.) } \\
\text { Mant. }\end{array}$ & $\begin{array}{l}\text { Asteracea } \\
\text { e }\end{array}$ & $\begin{array}{l}\text { Guntagala } \\
\text { gara }\end{array}$ & Herb & $\begin{array}{l}\text { FILARIASIS: Whole plant is ground into paste and mixed with oil is } \\
\text { applied on the affected areas. }\end{array}$ \\
\hline $\begin{array}{l}\text { Elephantopus scaber } \\
\text { Linn. }\end{array}$ & $\begin{array}{l}\text { Asteracea } \\
\text { e }\end{array}$ & $\begin{array}{l}\text { Eddu } \\
\text { adugu }\end{array}$ & Herb & $\begin{array}{l}\text { TONGUE DRYNESS: One spoon of root paste is administered with } \\
\text { water. }\end{array}$ \\
\hline $\begin{array}{l}\text { Emilia sonchifolia (L.) } \\
\text { DC. }\end{array}$ & $\begin{array}{l}\text { Asteracea } \\
\mathrm{e}\end{array}$ & $\begin{array}{l}\text { Garbapod } \\
\mathrm{u},\end{array}$ & Herb & $\begin{array}{l}\text { GALACTAGOGUE: One spoon of tuber paste is taken with water } \\
\text { daily once for } 5 \text { days. }\end{array}$ \\
\hline $\begin{array}{l}\text { Kalanchoe pinnata } \\
\text { (Lam.) Pers. }\end{array}$ & $\begin{array}{l}\text { Crassulac } \\
\text { eae }\end{array}$ & Ranapala & Herb & $\begin{array}{l}\text { BONE FRACTURE: Leaves ground into paste are plastered on the } \\
\text { affected bones to rejoin. }\end{array}$ \\
\hline $\begin{array}{l}\text { Lagenaria siceraria } \\
\text { (Molina) Standl. }\end{array}$ & $\begin{array}{l}\text { Cucurbita } \\
\text { ceae }\end{array}$ & $\begin{array}{l}\text { Anapa } \\
\text { kaya }\end{array}$ & Climber & BURNS: Leaf juice is applied on the burns twice a day till cure. \\
\hline $\begin{array}{l}\text { Leonotis nepetiifolia } \\
\text { (Linn.) R. Br. }\end{array}$ & $\begin{array}{l}\text { Lamiacea } \\
\mathrm{e}\end{array}$ & $\begin{array}{c}\text { Pedha } \\
\text { ranaberi }\end{array}$ & Herb & $\begin{array}{l}\text { RHEUMATIC PAINS: Twenty g of plant is made into decoction } \\
\text { with } 50 \mathrm{ml} \text { of water and administered daily for three days. }\end{array}$ \\
\hline Madhuca indica Gmel. & $\begin{array}{l}\text { Sapotacea } \\
\text { e }\end{array}$ & Ippa & Tree & $\begin{array}{l}\text { DOG BITE: Fifty g of stem bark is crushed and boiled in } 100 \mathrm{ml} \text { of } \\
\text { water till it is reduced to } 30 \mathrm{ml} \text {. The filtered decoction is administered } \\
\text { for twice on first day and once in the next day. }\end{array}$ \\
\hline $\begin{array}{l}\text { Manilkara hexandra } \\
\text { (Roxb.) Dubard. }\end{array}$ & $\begin{array}{l}\text { Sapotacea } \\
\text { e }\end{array}$ & Palachettu & Tree & $\begin{array}{l}\text { GALACTAGOGUE: Juice of stem bark is given daily once for 3-5 } \\
\text { days. It is also given to the lactating mothers daily once for 3-5 days. }\end{array}$ \\
\hline Melia azadirachta Linn. & Meliaceae & $\begin{array}{l}\text { Turaka } \\
\text { vepa }\end{array}$ & Tree & $\begin{array}{l}\text { MENSTRUAL DISORDERS: Two spoons of leaf juice mixed with } \\
\text { two spoons of honey is administered twice a day or quarter cup of } \\
\text { stem bark decoction is taken twice a day. }\end{array}$ \\
\hline $\begin{array}{l}\text { Mucuna pruriens (Linn.) } \\
\text { DC. }\end{array}$ & Fabaceae & $\begin{array}{l}\text { Dulakond } \\
\mathrm{i}\end{array}$ & Climber & $\begin{array}{l}\text { OEDEMA: Seed paste is applied on the swollen body to reduce } \\
\text { swellings and helps to remove water from the body. }\end{array}$ \\
\hline $\begin{array}{l}\text { Nyctanthes arbor-tristis } \\
\text { Linn. }\end{array}$ & $\begin{array}{l}\text { Nyctagina } \\
\text { ceae }\end{array}$ & Parijatam & Tree & $\begin{array}{l}\text { PILES: One seed is eaten daily and a portion of seed paste is applied } \\
\text { on the affected areas. }\end{array}$ \\
\hline Ocimum basilicum Linn. & $\begin{array}{l}\text { Lamiacea } \\
\mathrm{e}\end{array}$ & Thulasi & Terb & EARACHE: Leaves are crushed and leaf juice is poured into the ear. \\
\hline $\begin{array}{l}\text { Ocimum tenuiflorum } \\
\text { Linn. }\end{array}$ & $\begin{array}{l}\text { Lamiacea } \\
\mathrm{e}\end{array}$ & $\begin{array}{l}\text { Krishna } \\
\text { tulasi }\end{array}$ & Herb & $\begin{array}{l}\text { COUGH \& CATARRH: Leaf juice mixed with ginger juice and } \\
\text { honey of equal amounts is administered daily on empty stomach. Leaf } \\
\text { juice mixed with honey is given orally. }\end{array}$ \\
\hline $\begin{array}{l}\text { Oroxylum indicum } \\
\text { (Linn.)Vent. }\end{array}$ & $\begin{array}{l}\text { Bignoniac } \\
\text { eae }\end{array}$ & Pampanga & Tree & $\begin{array}{l}\text { COUGH \& JAUNDICE: Stem bark is ground with roots of } \\
\text { Phyllanthus amarus in equal quantities and one spoon of it is } \\
\text { administered daily once on empty stomach. }\end{array}$ \\
\hline Oxalis corniculata Linn. & $\begin{array}{l}\text { Oxalidace } \\
\text { ae }\end{array}$ & $\begin{array}{l}\text { Senchula } \\
\mathrm{m}\end{array}$ & Herb & $\begin{array}{l}\text { DYSENTERY \& NERVOUS WEAKNESS: One spoon of root } \\
\text { paste is administered with water daily once. }\end{array}$ \\
\hline Oxalis latifolia Kunth & $\begin{array}{l}\text { Oxalidace } \\
\text { ae }\end{array}$ & pulichinta & Herb & $\begin{array}{l}\text { PILES: Tuberous root is ground into paste and one spoon of it is } \\
\text { administered with water daily once. }\end{array}$ \\
\hline Passiflora foe & $\begin{array}{l}\text { Passiflora } \\
\text { ceae }\end{array}$ & $\begin{array}{l}\text { Gummari } \\
\text { theega }\end{array}$ & Herb & $\begin{array}{l}\text { GIDDINESS: One spoon of root paste is administered with half glass } \\
\text { of water. }\end{array}$ \\
\hline $\begin{array}{l}\text { Pavonia zeylanica (Linn.) } \\
\text { Cav. }\end{array}$ & $\begin{array}{l}\text { Malvacea } \\
\mathrm{e}\end{array}$ & $\begin{array}{l}\text { Karu } \\
\text { benda }\end{array}$ & Shrub & $\begin{array}{l}\text { DIARRHOEA: Two spoons of root decoction is administered daily } \\
\text { twice for } 2 \text { days. }\end{array}$ \\
\hline $\begin{array}{l}\text { Pergularia daemia } \\
\text { (Forsk.) Chiov. }\end{array}$ & $\begin{array}{l}\text { Asclipiada } \\
\text { ceae }\end{array}$ & $\begin{array}{l}\text { Dishtiver } \\
\mathrm{u}\end{array}$ & Shrub & $\begin{array}{l}\text { SWELLINGS: Crushed leaf juice mixed with lemon juice and } \\
\text { jaggery are made into paste and applied on the affected parts. }\end{array}$ \\
\hline $\begin{array}{l}\text { Phyllanthus emblica } \\
\text { Linn. }\end{array}$ & $\begin{array}{l}\text { Euphorbia } \\
\text { ceae }\end{array}$ & $\begin{array}{l}\text { Usiri } \\
\text { chettu }\end{array}$ & Tree & $\begin{array}{l}\text { DIABETES: Quarter cup of fruit juice is given orally with a pinch of } \\
\text { turmeric paste and honey daily once. }\end{array}$ \\
\hline $\begin{array}{l}\text { Pongamia pinnata (Linn.) } \\
\text { Pierre }\end{array}$ & Fabaceae & Kanuga & Tree & $\begin{array}{l}\text { PARALYSIS: Root or stem bark is heated in castor oil and used that } \\
\text { oil to massage the affected parts }\end{array}$ \\
\hline Rubia cordifolia Linn. & Rubiaceae & $\begin{array}{l}\text { Mangala } \\
\text { katthi }\end{array}$ & Herb & $\begin{array}{l}\text { JAUNDICE: Tuber ground into paste with that of Mirabilis jalapa } \\
\text { and made into pills. One pill each is administered daily thrice with } \\
\text { water on empty stomach. }\end{array}$ \\
\hline Ruellia tuberosa Linn. & $\begin{array}{l}\text { Acanthace } \\
\text { ae }\end{array}$ & $\begin{array}{l}\text { Jurubula } \\
\text { gadda }\end{array}$ & Herb & $\begin{array}{l}\text { BONE FRACTURE \& *SPRAINS: Leaves with those of Sida } \\
\text { cordifolia are crushed and gently massaged and bandaged on the } \\
\text { affected areas. }\end{array}$ \\
\hline $\begin{array}{l}\text { Saraca asoca (Roxb.) De } \\
\text { Willd }\end{array}$ & $\begin{array}{l}\text { Caesalpini } \\
\text { aceae }\end{array}$ & $\begin{array}{l}\text { Asoka } \\
\text { chettu }\end{array}$ & Tree & $\begin{array}{l}\text { MENORRHAGIA: One spoon of stem bark decoction is taken with } \\
\text { milk once a day. }\end{array}$ \\
\hline $\begin{array}{l}\text { Scindapsus officinalis } \\
\text { Schott }\end{array}$ & Araceae & Atukusaru & Climber & $\begin{array}{l}\text { BONE FRACTURE: Root is ground into paste and bandaged with } \\
\text { stem bark of Ceiba pentandra to rejoin the bones. }\end{array}$ \\
\hline Terminalia chebula Retz. & $\begin{array}{l}\text { Combreta } \\
\text { ceae }\end{array}$ & Karakkai & Tree & $\begin{array}{l}\text { SCIATICA: Unripe fruit powder with equal amounts of castor oil is } \\
\text { mixed and made into paste. One spoon of paste is administered daily } \\
\text { twice before going to bed. }\end{array}$ \\
\hline $\begin{array}{l}\text { Thalictrum foliolosum } \\
\text { DC. }\end{array}$ & $\begin{array}{l}\text { Ranuncula } \\
\text { ceae }\end{array}$ & Piyaranga & Herb & $\begin{array}{l}\text { RHEUMATISM: One spoon of root paste is administered with half } \\
\text { glass of water daily once for } 15 \text { days. }\end{array}$ \\
\hline Urena lobata Linn. & $\begin{array}{l}\text { Malvacea } \\
\mathrm{e}\end{array}$ & $\begin{array}{l}\text { Puliadugu } \\
\text { mokka }\end{array}$ & Herb & $\begin{array}{l}\text { STOMACHACHE: Root paste mixed with half cup of water is } \\
\text { administered twice a day for } 2 \text { days. }\end{array}$ \\
\hline Urginea indica & Liliaceae & Adavi ulli & Herb & MENSTRUAL DISORDERS: A quarter cup of decoction made up \\
\hline
\end{tabular}




\begin{tabular}{|l|l|l|l|l|}
\hline (Roxb.)Kunth & & & $\begin{array}{l}\text { of bulbs ground with tubers of Nymphaea pubescens (red variety) and } \\
\text { Musa paradisiaca. is taken daily once. }\end{array}$ \\
\hline $\begin{array}{l}\text { Vernonia anthelmintica } \\
\text { (Linn.) Willd. }\end{array}$ & $\begin{array}{l}\text { Asteracea } \\
\text { e }\end{array}$ & $\begin{array}{l}\text { Neeru } \\
\text { visham } \\
\text { soap nut seed sized tablets. One tablet is administered daily once for 3 } \\
\text { days. }\end{array}$ & Herb & $\begin{array}{l}\text { WOUNDS: Equal amounts of leaves and rhizome of Curcuma longa } \\
\text { are ground into paste and applied on the affected areas. }\end{array}$ \\
\hline $\begin{array}{l}\text { Vernonia cinerea } \text { (Linn.) } \\
\text { Less. }\end{array}$ & $\begin{array}{l}\text { Asteracea } \\
\text { e }\end{array}$ & Sahadevi & Herb & $\begin{array}{l}\text { SNAKE BITE: Handful of tender leaves are crushed and eaten to get } \\
\text { vomiting and also acts as an antidote. }\end{array}$ \\
\hline $\begin{array}{l}\text { Wattakaka volubilis } \\
\text { (Linn. } \text {.) Stapf. }\end{array}$ & $\begin{array}{l}\text { Asclepiad } \\
\text { aceae }\end{array}$ & Palateega & Climber \\
\hline $\begin{array}{l}\text { Woodfordia fruticosa } \\
\text { (Linn.) Kurz }\end{array}$ & $\begin{array}{l}\text { Lythracea } \\
\text { e }\end{array}$ & Jagipuvvu & Shrub & $\begin{array}{l}\text { MENSTRUAL DISORDERS: Flower powder is taken with milk } \\
\text { mixed with sugar daily once. }\end{array}$ \\
\hline $\begin{array}{l}\text { Wrightia tinctoria } \text { (Roxb.) } \\
\text { R. Br. }\end{array}$ & $\begin{array}{l}\text { Apocynac } \\
\text { eae }\end{array}$ & Ankudu & Tree & $\begin{array}{l}\text { INTOXICANT: Bark is mixed in the toddy preparation to get } \\
\text { intoxication. }\end{array}$ \\
\hline $\begin{array}{l}\text { Zanthoxylum armatum } \\
\text { DC. }\end{array}$ & Rutaceae & $\begin{array}{l}\text { Tella } \\
\text { kasimi }\end{array}$ & Shrub & $\begin{array}{l}\text { DYSENTERY \& *VMITINGS IN CHILDREN: Dried leaves } \\
\text { with those of neem and turmeric mixed with water are made into } \\
\text { small tablets and one tablet is administered daily once. }\end{array}$ \\
\hline Zingiber officinale Rosc. & $\begin{array}{l}\text { Zingibera } \\
\text { ceae }\end{array}$ & Allamu & Herb & $\begin{array}{l}\text { COLD, COUGH \& ASTHMA: One spoon of rhizome juice taken } \\
\text { with equal quantity of honey is administered early in the morning. }\end{array}$ \\
\hline $\begin{array}{l}\text { Zizyphus mauritiana } \\
\text { Lam. }\end{array}$ & $\begin{array}{l}\text { Rhamnace } \\
\text { ae }\end{array}$ & Regu & Tree & $\begin{array}{l}\text { DENTAL DISORDERS: Leaf decoction is used to gargle daily twice } \\
\text { to cure bad smell, mouth ulcers and disorders. }\end{array}$ \\
\hline
\end{tabular}

\section{RESULT \& DISCUSSION}

A total number of 68 plants belonging to 40 families were recorded (Table 1). Asteraceae has the highest number of species (7 species) followed by Fabaceae (5 species), Caesalpiniaceae (4 species), Araceae, Cucurbitaceae, and Lamiaceae (3species each) Rutaceae, Apocynaceae, Liliaceae, Meliaceae, Sapotaceae, Oxalidaceae, Malvaceae, and Asclepiadaceae ( 2 species each) and rest of the families contain one species each. Among the total plant species, Herbs are highest in number (29) followed by Trees (18), Shrubs (8) and Climbers, Stragglers, Lians and Creepers (13). With regard to the frequency of plant parts used in preparations, stem bark was most often used followed by roots, leaves, whole plant, roots, seeds and tubers etc. The Konda dora tribes used Acorus calamus Linn. plant for fever; Rhizome paste is applied all over the body and a pinch of rhizome or leaf paste is administered with a glass of water only once to keep away evil spirits causing fever. Butea superba Roxb. flowers are ground with the leaves of Cinnamomum zeylanicum and the paste is administered orally twice a day for snake bite. Alangium salvifolium (Linn.) flower buds mixed with Phyllanthus emblica fruit and turmeric in equal quantities are made into powder. One spoon of it mixed with honey is administered once a day to cure diabetes. Konda dora tribes expert some of the disease like jaundice, piles, stomachache etc., plant of Ruellia tuberosa Linn, is used for bone fracture. It is noted that the Konda dora use most of the medicinal plants to cure their day to day health problems like diarrhea, dyspepsia, general fevers, skin diseases, menstrual problems, joint pains, wounds, snake bite etc.

The survey indicated that, the study area was rich in medicinal plants useful to treat a wide spectrum of human ailments. The tribal people are treasures of traditional knowledge of plants from utilitarian point of view. They have successful art of curing diseases in several localities of the district. Frequent field surveys and regular personal interviews in different pockets revealed 35 diseases treated with 68 medicinal plants.

It is observed that in majority of cases a single plant is administered singly but for a good number of diseases also the recipe includes a combination of many plants and plant parts. At the same time it was seen that a single herbal recipe is effective for treatment of a number of ailments, which shows that a single plant is used for more than one ailment. The crude is either used singly or in combination with other materials of plant, animal or mineral origin. Such medicines are prepared under special method of heating, roasting, extraction with water, oil, milk, fat or even animal urine, fermentation under specifically controlled condition or regulated grinding. 

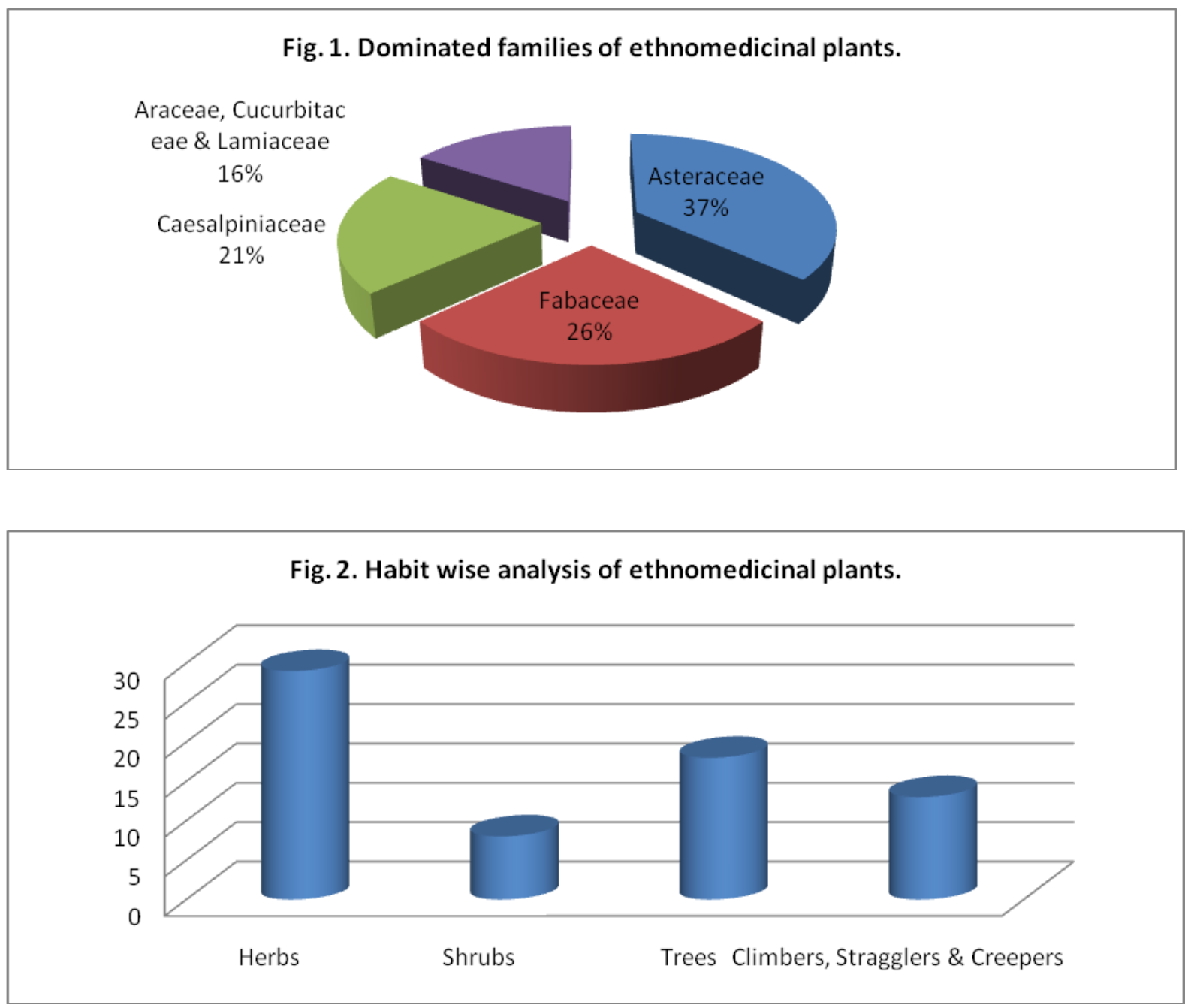

\section{CONCLUSION}

Due to constant association with the forest environment, they have evolved knowledge by trial and error and have developed their own way of diagnosis and treatment for different ailments. The ethnic drug formulations need clinical tests to prove their efficacy and also to develop new herbal drugs for the effective treatment. This data provides basic source for further studies aimed at conservation, cultivation, improvement of ethnic traditional medicine and economic welfare of rural and tribal population of the region. The traditional botanical knowledge will provide secure livelihood to the native tribes that minimize the resource depletion, environmental degradation, cultural disruption and social instability. The medico-botanical survey of the area revealed that the people of the area possessing good knowledge of herbal drugs but as the people are in progressive exposure to modernization, their knowledge of traditional uses of plants may be lost in due course. So it is important to study and record the uses of plants by different tribes and sub-tribes for futures study. Such studies may also provide some information to biochemists and pharmacologists in screening of individual species and in rapid assessing of phytoconstituents for the treatment of various diseases.

\section{ACKNOWLEDGEMENT}

The authors are thankful to the notified and denotified adivasi groups, their vaids, ojhas, bhopas etc. and forest officials who provided valuable information on this subject. We are also thankful to the authorities of various herbaria and, museums for their help and co-operation extended in several ways. 


\section{REFERENCE:}

[1]. Anonymous, Ethno biology in India: A Status Report. Ministry of Environment \& Forests, Govt. of India, New Delhi, 1990, 1 $68 \mathrm{pp}$.

[2]. Hemadri, K. Rheumatism: tribal medicine. Anc. Sci. Life 1981, 1: 117-120.

[3]. Hemadri, K. \& S.S. Rao. Leucorrhoea and menorrhagia: Tribal medicine. Anc. Sci. Life. 1983, 3: 40-41

[4]. Hemadri, K \& S.S. Rao . Jaundice: Tribal medicine. Anc. Sci. Life, 1984, 4: 209-212.

[5]. Ramarao, N. The Ethnobotany of Eastern Ghats in Andhra Pradesh, India. Ph.D. thesis. 1988, Bharathiar University, Coimbatore.

[6]. Jain, S.K.. Dictionary of Indian Folk Medicine and Ethnobotany. Deep Publications, 1991, New Delhi.

[7]. Basi Reddy, M., K. Raja Reddy and M. N. Reddy. Ethnobotany of Cuddapah district, Andhra Pradesh, India. Int. Journ. Pharmacogn., 1991, 29: 1-8.

[8]. Billore, K. V., T. G. Joseph and S. K. Dave, Interesting folk remedies by the Local vaidyas of Rajasthan for Swas Roga. Ethnobotany, 1998, 10: 42-45.

[9]. Chandra, K. and H. C. Pandey. Collection of plants around Agora Dodltal in Uttarakashi district of Uttar Pradesh with medicinal values and folk-lore claims. Int. J. Crude Drug Res., 1983, 21: 21-28.

[10]. Das, P. K. and R. Kanth. Ethnobotanical studies of the tribal belt of Koraput (Orissa). Bull. Medico Ethn. Bot. Res., 1998, 9(34): $123-128$.

[11]. Girach, R. D. and Aminuddin. Ethnomedicinal uses of plants among the tribals of Singbhum District, Bihar, India. Ethnobotany, 1995, 7: $103-107$.

[12]. Hema, L \& N. Yesodamma. Importance of Medicinal Plants of Ardhagiri hill, Chittoor district, Andhra Pradesh. International Seminar on Medicinal Plants and Herbal products. 2008, $7^{\text {th }}-9^{\text {th }}$ March. Page. 45.

[13]. Jain, S. K. Studies on Indian Ethnobotany - Less known uses of 50 common plants from tribal areas of Madhya Pradesh. Bull. Bot. Surv. India, 1963, 5(3-4): 223-226.

[14]. Katewa, S. S., Ambika Nag and Buddhadev Guria. Ethnobotanical studies on wild plants for food from the Aravalli hills of South - east Rajasthan. J. Eeon. Tax Bot., 1999, 23: 259-264

[15]. Kumar, A. K. and K. Niteswar. An enquiry into the folk lore medicines of Addateegala an agency tract of East Godavari District of Andhra Pradesh. Indian Medicine, 1983, 2: 2-4. 